\title{
ГЕЛЬ «ФЛЮРОСКАН» ДЛЯ ДИАГНОСТИКИ НОВООБРАЗОВАНИЙ КОЖИ И СЛИЗИСТЫХ ОБОЛОЧЕК РАЗЛИЧНОЙ ЭТИОЛОГИИ
}

\author{
В.Д. Румянцева', А.Е. Щелкунова', Ю.В. Алексеев² \\ 1МИРЭА - Российский технологический университет, \\ 119571, Россия, Москва, пр-т Вернадского, 86. \\ 2ФГБУ «ГНЦ лазерной медицины им. О.К. Скобелкина ФМБА России», \\ 121165, Россия, Москва, ул. Студенческая, 40.
}

DOI: 10.19163/MedChemRussia2021-2021-428

E-mail:vdrum@mail.ru

Порфирины и их металлокомплексы нашли применение наряду с различными областями науки и техники также в биологии и медицине. Их используют в иммунофлуоресцентном анализе, фотодинамической терапии и фотодиагностике новообразований и др. В методе лазерной медицинской визуализации и анализа биотканей на наличие патологии наиболее перспективным подходом является лазерный флуоресцентный анализ. Использование Yb-комплексов порфиринов (ИКП), люминесцирующих в ближнем ИКдиапазоне (700 - 1100 нм), и лазерно-волоконного флуориметра позволяет успешно проводить люминесцентную диагностику рака и других новообразований.

Исходя из гемина крови крупного рогатого скота был отработан препаративный лабораторный метод синтеза Yb-комплекса 2,4-ди( $\alpha$-метоксиэтил) дейтеропорфирина IX [1]. На его основе созданы амфифильные композиции с различными гелями (тизоль, калгель, кремофор) под названием «Флюроскан» (декларация о соответствии № POCC RU.0001.510608). Разработана методика качественного и количественного определения Yb-комплекса порфирина в составе геля «Флюроскан». Для подтверждения подлинности препарата предложено использовать данные электронных спектров поглощения ИКП в ДМСО. Для характеристики ИКП в геле применяется отношение оптических плотностей при 568 нм к оптической плотности при 532 нм (диапазон в интервале 1.13 - 1.20). Проведены предварительные испытания геля для люминесцентной диагностики в дерматологии и гинекологии. Показано его эффективное накопление в патологически измененных участках тканей и слизистых оболочек, что свидетельствует о перспективности применения геля в люминесцентной диагностике.

Работа выполнена при финансовой поддержке Министерства науки и высшего образования РФ (проект № 0706-2020-0019).

\section{Литература}

[1] А.Е. Щелкунова, Е.В. Болтухина, В.Д. Румянцева, И.П. Шилов, С.Д. Каракотов, Макрогетероциклы. 2019, 12, 382-388. 